\title{
Obywatel patriota? Patriotyzm jako czynnik determinujący aktywność obywatelską młodych Polaków
}

\begin{abstract}
Streszczenie: Niniejszy artykuł stanowi propozycję spojrzenia na kategorię patriotyzmu jako na czynnik, który może odegrać istotną rolę w procesie budowy społeczeństwa obywatelskiego w państwie postkomunistycznym. Głównym celem jest analiza i wyjaśnienie, w jakim stopniu (i w jakim zakresie) patriotyzm polskich studentów wpływa na prawdopodobieństwo podejmowania zachowań obywatelskich, prospołecznych i prodemokratycznych. Poszukując odpowiedzi na to pytanie, autor zweryfikował szereg hipotez zakładających związek patriotyzmu (rozumianego na różne sposoby) z zachowaniami i poglądami, które są funkcjonalne z punktu widzenia jakości demokracji. Podstawą analiz były dane z ogólnopolskiego badania ankietowego zrealizowanego wśród studentów z 14 największych uniwersytetów w Polsce w okresie między styczniem a majem 2018 roku $(\mathrm{N}=980)$. Wyniki analizy statystycznej prowadzą do generalnej konkluzji, że patriotyzm stanowi względnie słaby, ale istotny predyktor postaw obywatelskich.
\end{abstract}

Słowa kluczowe: patriotyzm, konstruktywny patriotyzm, ślepy patriotyzm, aktywność obywatelska, społeczeństwo obywatelskie, młodzież

\section{Wprowadzenie $^{1}$}

$\mathbf{W}$ spółwystępowanie przeciwności, szans i zagrożeń, czynników funkcjonalnych destrukcyjnych dla zjawisk społecznych stanowi rys charakterystyczny współczesnego ponowoczesnego świata. Trendy i tendencje stają się niejednokrotnie źródłem kontrtrendów i kontrtendencji. Zmiana i innowacja rodzi reakcje obronne, a - z pozoru - hegemoniczne projekty ustępują miejsca innym, których dominacja w przyszłości zostanie również podważona (Mouffe, 2015). Nie oznacza to jednak, że obywatele demokratycznych społeczeństw, a w szczególności elity polityczne, powinni ignorować ten swoisty rodzaj wyobraźni, która zdaniem Charlesa W. Millsa pozwala połączyć losy jednostki z wielkimi trendami i zmianami strukturalnymi na świecie, a w konsekwencji przeciwstawiać się fatalizmowi i determinizmowi w myśleniu o otaczającej nas rzeczywistości społeczno-politycznej (Mills, 1959). Instytucje demokratyczne - takie jak szkoła, uniwersytet, media masowe, partie polityczne - mogą bowiem substancjalnie wpływać na postawy obywateli. Dotyczy to w szczególności młodych pokoleń, tworzonych przez tzw. democratic natives (Marzęcki, 2015, 2017), którzy odegrać mogą katalizującą rolę w budowie nowoczesnych społeczeństw obywatelskich w krajach postkomunistycznych (Szafraniec i in., 2017). Promowanie funkcjonalnych postaw wśród młodzieży może - i powinno - stawać się instytucjonalnym celem w długiej perspek-

${ }^{1} \mathrm{~W}$ niniejszym artykule wykorzystano dane uzyskane $\mathrm{w}$ ramach projektu badawczego finansowanego ze środków Narodowego Centrum Nauki (nr grantu: 2016/23/D/HS5/00902). 
tywie. Choć w praktyce niezwykle trudno jest zaprojektować czy przewidzieć efekt transformacji, to żadnej zmiany nie można skutecznie wprowadzić w życie, jeśli nie wyobrazimy sobie wcześniej jej projektu zorientowanego na przyszłość (Federowicz, 2000, s. 91). Ów wpływ na rzeczywistość będzie większy, jeśli instytucje będą w stanie odpowiednio diagnozować wektory społecznych trendów oraz istotę zjawisk, ich złożoność i wielowymiarowość. Takie programowanie konstruktywnych prodemokratycznych postaw, polegające na racjonalnym uwalnianiu pozytywnej energii młodych ludzi i orientowaniu jej na funkcjonalne cele, powinno być wyzwaniem dla wszystkich podmiotów, które realizują elementy tzw. polityki młodzieżowej. Dlatego też niniejszy artykuł stanowi próbę takiego właśnie refleksyjnego spojrzenia na rzeczywistość, która nas otacza, i którą współtworzymy zarazem, tak, aby móc z sensem odpowiedzieć na pytanie o to, w jakie postawy młodzieży warto dzisiaj inwestować, mając na względzie jakość polskiej „,demokracji jutra” (Marzęcki, Stach, 2016). Wyzwanie, o którym mowa jest jeszcze trudniejsze w świecie, w którym, integracja i fragmentaryzacja, globalizacja i terytorializacja jako przykłady kontrtendencji stanowią istotę mechanizmu zmiany społecznej (Bauman, 1997; Urry, 2003; Ray, 2007). Przy użyciu podobnego dialektycznego schematu opisuje teraźniejszość Jan Zielonka, zderzając ze sobą dwie perspektywy: po pierwsze, rewolucji, która zainicjowała procesy demokratyzacji w krajach Europy Środkowej i Wschodniej po 1989 roku, a której dziedzictwem było to, że „zniosła granice dla przepływu ludzi, idei i towarów, zbudowała systemy prawne i demokratyczne, oczyściła stosunki międzynarodowe z pozostałości systemu westfalskiego" (Zielonka, 2018, s. 11). Po drugie, kontrrewolucji, która stanowi wyraz kontestacji dotychczasowego porządku. W swoim antyliberalnym wydźwięku, stanowi ona zagrożenie dla społeczeństwa otwartego, prowadzi do rozmontowania projektu demokratycznego tak na wschodzie, jak i na zachodzie Europy oraz ekspansji populizmu. Jej siłą napędową są przekonania dużej części współczesnych społeczeństw o nieskuteczności i niesprawności ponadnarodowego modelu zarządzania ich problemami. To one stają się dzisiaj podłożem dla rozkwitu politycznych narracji, które akcentują konieczność powrotu do narodowych tożsamości, przy użyciu takich kategorii, jak godność, suwerenność, interes narodowy, patriotyzm. Z drugiej strony, trudno nie zauważyć, że procesy globalizacyjne osłabiły legitymizację władzy w państwach narodowych i spowodowały, że jej ośrodek przeniósł się częściowo na poziom transnarodowy, determinując pośrednio nowe formy obywatelstwa czy tożsamości. Coraz częściej mówimy o potrzebie konstruowania zbiorowej tożsamości (np. europejskiej), czegoś, co Jürgen Habermas i Jacques Derrida określają mianem „wspólnej mentalności politycznej” (Habermas, Derrida, 2003, s. 23). Takie zjawiska i tendencje, jak uniwersalizacja, fragmentaryzacja, a dodatkowo multiplikacja tożsamości zachodzą dzisiaj jednocześnie. Zjawisko to widoczne jest zarówno na poziomie politycznych dyskursów elit symbolicznych (linie argumentacyjne są wyznaczane przez afiliacje i sympatie partyjne), ale także w poglądach, opiniach, światopoglądach, hierarchiach wartości, zachowaniach (także wyborczych) zwykłych obywateli. Obserwujemy odrodzenie (a raczej położenie silniejszego akcentu) lokalnych (przede wszystkim narodowych) identyfikacji, podkreślanie narodowej wyjątkowości czy odmienności, prymatu interesu państwa i narodu nad zobowiązaniami wobec innych państw i narodów, powrót w debacie publicznej do idei patriotyzmu (np. w jego gospodarczej odmianie). Nastroje społeczne w tym zakresie są jednak często stymulowa- 
ne przez elity instrumentalnie poprzez wywoływanie określonych emocji u obywateli. W wielu krajach postkomunistycznych pojęcie patriotyzmu jest wykorzystywane cynicznie w populistycznych dyskursach. Rzadziej bywa przedmiotem merytorycznej debaty, w której elity symboliczne - wobec zainteresowanego audytorium - mogą otwarcie dyskutować i negocjować jego zakres znaczeniowy. Częściej budzi skrajne emocje i służy raczej do kategoryzowania ludzi na ,złych” i ,dobrych” patriotów. Długofalowy plan kształtowania konstruktywnych postaw obywatelskich ustępuje presji bycia skutecznym w bieżącej polityce. Kategoria patriotyzmu została wręcz zawłaszczona przez współautorów narodowych i populistycznych dyskursów, napędzając fanatyzm, szowinizm i konflikty, przez co staje się narzędziem marginalizowania i wykluczania mniejszości z kręgu „my” (Ariely, 2018). Brak rzeczowej dyskusji nad rolą i znaczeniem patriotyzmu we współczesnym społeczeństwie powoduje, iż rzadko dostrzega się fakt, że może on być swoistą orientacją nabytą w procesie socjalizacji, a przez to determinować poglądy, idee i percepcję rzeczywistości całych pokoleń (Druckman, 1994). W takich krajach, jak Polska, autoidentyfikacje patriotyczne są jednak wciąż bardzo silne. Wedle danych CBOS z sierpnia 2018 roku 88\% Polaków uważa się za patriotę, a 71\% odczuwa dumę z faktu bycia Polakiem (Patriotyzm Polaków, 2018). Wydaje się zatem konieczne, aby spojrzeć na kategorię patriotyzmu w sposób bardziej użyteczny społecznie - jako na czynnik, który może odegrać istotną rolę w procesie budowy społeczeństwa obywatelskiego. Czy w patriotyzmie polskiego społeczeństwa - szczególnie młodego pokolenia - tkwi (i jaki?) prospołeczny, obywatelski, prodemokratyczny potencjał? Odpowiedź na to pytanie powinna być inspiracją, ale i wyzwaniem dla rozmaitych demokratycznych instytucji oraz elit symbolicznych, które nie są dostatecznie przekonane, że otwarte i aktywne społeczeństwo można skutecznie budować także wokół takich wartości, jak patriotyzm, wspólnota narodowa, miłość do ojczyzny². W kolejnych sekcjach artykułu zostaną zaprezentowane: 1) przegląd literatury dotyczącej patriotyzmu jako determinanty zachowań prospołecznych; 2) metodologia badań, będących podstawą analiz i prezentowanych wniosków; 3) omówienie wyników badań nad patriotyzmem polskich studentów; 4) interpretacja uzyskanych danych w kontekście dotychczasowych ustaleń oraz najważniejsze konkluzje.

\section{Dwa oblicza patriotyzmu. Przegląd literatury}

Jeden z podstawowych dylematów badaczy patriotyzmu dotyczy tego, jak mierzyć to zjawisko. To oczywiste - w badaniach społecznych w ogóle - że brakuje nam precyzyjnych narzędzi, aby uzyskiwać powtarzalne, trafne i rzetelne wyniki naszych pomiarów. W tym przypadku kluczowe okazuje się jednak również podejście teoretyczne do kwestii patriotyzmu. Dlatego też odpowiednio wcześnie należy rozstrzygnąć nie tyle to, jak mierzyć, ale: co mierzyć? Przedmiotem diagnozy mogą być zatem: 1) autoidentyfikacje patriotyczne (poczucie bycia patriotą); 2) rozumienie patriotyzmu (wówczas uzyskane

${ }^{2}$ Tożsamość ponadnarodowa (np. europejska) nie musi się bowiem kłócić z tożsamością narodową, podobnie jak tożsamość narodowa nie musi wykluczać przywiązania i identyfikacji z tym, co lokalne. W określonych sytuacjach tożsamość narodowa może nawet wpływać na identyfikację z Europą (Lewicki, 2004, s. 24). 
dane pozwalają na opisanie obrazu/ów patriotyzmu, które funkcjonują w świadomości społecznej); 3) postawy patriotyczne (wszystkie ich komponenty: wiedza i poglądy, emocje, zachowania ${ }^{3}$ ); 4) tożsamość narodowa; 5) postawy na skali od etnocentryzmu do kosmopolityzmu (Nathanson, 1989, 2008) czy 6) patriotyzm lokalny, który manifestuje się zupełnie inaczej niż ten klasycznie rozumiany.

W literaturze politologicznej, socjologicznej, psychologicznej czy historycznej odnajdujemy wiele zróżnicowanych podejść do definiowania patriotyzmu, potwierdzających istnienie różnych perspektyw badawczych, ale i problematyczność samego pojęcia. Niektórzy badacze stwierdzają wprost - choć metaforycznie - że patriotyzm ma wiele twarzy (Abbott, 2007; Finell, Zogmaister, 2015), zwracając przy tym uwagę na wielowymiarowość tego zjawiska, które wciąż bywa przedmiotem sporów i debat teoretyków polityki oraz badaczy społecznych (Ariely, 2018). W polskim dyskursie akademickim próby definiowania patriotyzmu najczęściej sprowadzają się do przytaczania i dekonstrukcji jego słownikowego znaczenia i etymologii ${ }^{4}$, jak również wyjaśnień w oparciu o opis historycznie zaobserwowanych postaw jednostek i grup społecznych ${ }^{5}$. Na gruncie zachodnioeuropejskiej czy amerykańskiej literatury naukowej dominuje z kolei refleksja teoretyczna, która najczęściej służy jako fundament dla operacjonalizacji konstruktu empirycznego (Conover, Feldman, 1987; Karasawa, 2002; Kosterman, Feshbach, 1989; Huddy, Khatib, 2007; Richey, 2011). W większości tych ujęć utożsamia się patriotyzm $\mathrm{z}$ aspektem afektywnym postawy (stąd przynajmniej w domyśle zakłada się jego determinującą funkcję względem aspektu behawioralnego), akcentując stan emocjonalny, który towarzyszy jednostce wobec obiektu, jakim jest jej własny kraj (mianowicie: jego kultura, wartości, terytorium, ustrój polityczny, historia i mity narodowe, rząd i polityka, społeczeństwo) (Theiss-Morse, 2009, s. 23). Relacja jednostka-kraj/naród opisywana jest przy użyciu takich kategorii jak przywiązanie, lojalność (Druckman, 1994), miłość i duma (Federico, Golec, Dial, 2005), a patriotyczne uczucia są często przedstawiane jako wskaźnik tożsamości społecznej (Tajfel, 1974; Tajfel i in., 1971), który pomaga obywatelom dokonywać samokategoryzacji i przypisania do określonej grupy społecznej, także takiej, jak społeczność lokalna. Patriotyzm jest określany jako jedna z najważniejszych form przywiązania grupowego we współczesnym świecie (Schatz, Staub, Lavine, 1999, s. 152), choć już w latach 50. XX wieku zwracano uwagę na dualną funkcję społeczną tego rodzaju identyfikacji z narodem. Przykładem mogą być prace Theodora Adorno i współpracowników, w których po raz pierwszy tak wyraźnie zaakcentowano dystynkcję pomiędzy ,pseudo-patriotyzmem” oraz „,patriotyzmem autentycznym” (genuine patriotism). Ten pierwszy był utożsamiany ze ślepym przywiązaniem do określonych wartości kulturowych, z konformizmem wobec dominujących wzorów postępowania oraz odrzuceniem innych narodów traktowanych jako „obce” (Adorno i in., 1950, s. 107). Drugi natomiast, miał oznaczać wyraz miłości do kraju oraz przywiązanie do wartości narodowych, opartych na krytycznej refleksji (Tajfel, 1974). To dwoiste ujęcie było i wciąż jest powielane w wielu współczesnych pracach, których autorzy: 1) spierają

${ }^{3} \mathrm{~W}$ tym przypadku najbardziej interesujące będą próby ustalenia związków pomiędzy wiedzą i emocjami na skali patriotyzmu a zachowaniami, np. aktywnością obywatelską.

${ }^{4}$ Warto przytoczyć pracę Małgorzaty Brzozowskiej (2014, s. 44-49), która dokonuje swoistego przeglądu i usystematyzowania definicji słownikowych pojęcia patriotyzm.

${ }^{5}$ Dobrym przykładem są prace Andrzeja Walickiego (1991) czy Andrzeja Nowaka (2005). 
się co do natury patriotyzmu (dobry/zły); 2) dopatrują się przede wszystkim pozytywnej roli patriotyzmu w procesie konstruowania tożsamości społecznej, przeciwstawiając go rozmaitym formom dyskryminacji międzygrupowej, jak rasizm, etnocentryzm czy nacjonalizm (Heaven, Rajab, Ray, 1985; Kosterman, Feshbach, 1989; Ray, Furnham, 1984; Ray, Lovejoy, 1986) ${ }^{6}$; 3) względnie dokonują jednoznacznego rozróżnienia pomiędzy funkcjonalną i destrukcyjną jego odmianą.

Badacze, którzy wykorzystują patriotyzm jako konstrukt empiryczny zwracają uwagę na funkcjonalne efekty tego emocjonalnego zaangażowania w życie wspólnoty (stąd określenie civic virtue), które manifestują się w zachowaniach jednostek. Ten fakt zauważa przykładowo Gal Ariely (2018), który wskazuje, że patriotyzmowi przypisuje się kluczowe znaczenie dla integracji mniejszości i wzmacniania spójności społecznej. Inni wskazują na szereg kolejnych pozytywnych skutków społecznych patriotyzmu, m.in. fakt, że sprzyja nawiązywaniu współpracy z innymi członkami wspólnoty (Gangl, Torgler, Kirchler, 2016; Cialdini, Goldstein, 2004; Blader, Tyler, 2009; Terry, Hogg, White, 1999), stymuluje odpowiedzialność i uczciwość obywateli (Whiteley, 1999) oraz poczucie solidarności (Ariely, 2018), redukuje konflikt społeczny, sprzyja aktywnemu obywatelstwu (Müller, 2007; Soutphommasane, 2012; Huddy, Khatib, 2007; Bar-Tal, 1993; Putnam, 2000), a nawet wzmacnia poczucie obowiązku w zakresie płacenia podatków (Gangl, Torgler, Kirchler, 2016). Daniel Bar-Tal (1993, s. 55-58) zwraca uwagę na funkcje jednostkowe (umacnia poczucie przynależności, wspiera definicję społecznej tożsamości jednostki) oraz grupowe (przyczynia się do integracji społeczeństwa, wzmacnia spójność grupową, mobilizuje członków grupy do działania w jej imieniu, przyczynia się do podejmowania wysiłków, poświęcania czasu i pieniędzy dla grupy). W tym sensie może być traktowany jako swoisty kapitał społeczny, który sprzyja zachowaniom prospołecznym (Rothstein, 2003; Gangl, Torgler, Kirchler, 2016, s. 869). Z drugiej strony - choć o wiele rzadziej - eksponuje się fakt, iż patriotyzm bezpośrednio napędza fanatyzm, szowinizm i konflikty, przez co staje się narzędziem marginalizowania i wykluczania mniejszości z kręgu „my” (zob. także Kateb, 2006). Obok postulatów, by kreślić czytelną granicę między patriotyzmem a etnocentryzmem (Bar-Tal, 1993, s. 51-52), pojawiają się zatem słuszne uwagi, iż oba zjawiska mogą być ze sobą ściśle powiązane i się przenikać. Patriotyzm (w pozytywnym znaczeniu) może być monopolizowany przez pewne grupy, które wykorzystują go instrumentalnie, podporządkowując partykularnej ideologii, celom lub środkom działania (Bar-Tal, 1993, s. 58). Te odmienne sposoby identyfikacji winny być - zdaniem innych - jednoznacznie rozgraniczane. Warto odnotować, że wspólne psychologiczne podłoże może sprzyjać rozprzestrzenianiu się zarówno „zdrowego” patriotyzmu, jak i „destrukcyjnego” nacjonalizmu (Kosterman, Feshbach, 1989). Ten pierwszy wpisuje się w koncepcję, którą Leonie Huddy i Nadia Khatib (2007, s. 63) określają mianem ,szerokiego porozumienia co do znaczenia patriotyzmu"), na które składa się: 1) pozytywna identyfikacja oraz 2) afektywne przywiązanie do własnego kraju (poprzez odczuwanie emocji: miłości do kraju i dumy z osiągnięć kraju), wyrażające się również emocjonalnymi reakcjami na symbole narodowe (Gangl, Torgler, Kirchler, 2016, s. 868; Schatz, Staub, Lavine, 1999, s. 152; Wolak, Dawkins, 2017, s. 392). Ten drugi, zakłada hierarchiczne postrzeganie świata i odzwier-

${ }^{6} \mathrm{~W}$ literaturze przedmiotu pojawiają się też koncepcje, traktujące patriotyzm jako źródło negatywnych postaw społecznych, np. szowinizmu czy dążenia do konfliktów (Nussbaum, 2002; Kateb, 2006). 
ciedla przekonanie, że własny kraj jest lepszy od innych i powinien zajmować pozycję dominującą (Federico, Golec, Dial, 2005; Blank, Schmidt, 2003). W przeciwieństwie do postaw i poglądów opartych na etnocentryzmie i odwołujących się do nacjonalizmu, patriotyzm nie jest związany z uprzedzeniami czy wrogością wobec grup „obcych” (de Figueiredo, Elkins, 2003; Druckman, 1994, s. 63-64).

To, w jaki sposób patriotyzm postrzegany jest jako determinanta zachowań ludzkich i jak są klasyfikowane jego społeczne skutki zależy od sposobu konceptualizacji samego pojęcia. Uwaga ta dotyczy zarówno dyskursów prywatnych, jak i medialnych, politycznych oraz naukowych. Być może warto więc rozstrzygnąć ważny dylemat badacza poprzez wyeksponowanie dwóch odmian patriotyzmu: funkcjonalnej i dysfunkcjonalnej. Użytecznym rozwiązaniem - na gruncie teoretycznym, ale i empirycznym - może być propozycja rozróżnienia na tzw. konstruktywny (constructive) ${ }^{7}$ oraz ślepy (blind) patriotyzm. Obie orientacje mają analogiczny fundament (pozytywna identyfikacja oraz afektywne przywiązanie do własnego kraju/narodu), jednakże cechują się zupełnie odmienną percepcją otaczającego świata. Odróżniają je przede wszystkim czynniki determinujące lojalność jednostki wobec wspólnoty narodowej i kraju, ale również rozbieżne sposoby ich wartościowania (czy wręcz hierarchizowania). „Ślepy” patriotyzm odznacza się „bezwzględnym przywiązaniem do kraju, które wyraża się w jednostronnie pozytywnych ocenach, wiernej lojalności i nietolerowaniu krytyki” grupy „własnej” (Schatz, Staub, Lavine, 1999, s. 153), którym towarzyszą negatywne przekonania na temat grup „obcych” (out-groups) (Finell, Zogmaister, 2015). Z kolei patriotyzm konstruktywny ma oznaczać taki rodzaj więzi z krajem, który charakteryzuje się „krytyczną lojalnością”, pomagającą przeciwstawiać się dyskryminacji i wspierającą pragnienie realizacji pozywanych zmian (Schatz, Staub, Lavine, 1999, s. 153). Stanowi on orientację na zmianę społeczną (rozumianą także jako reformę; Sekerdej, Roccas, 2016), która - obiektywnie - ma pozytywny charakter, i której beneficjentami są przedstawiciele wielu grup i warstw społecznych (Staub, 1997). Motywem działania takiego ,krytycznego patrioty" jest demokratyczne przekonanie, że należy się przeciwstawiać wszelkim praktykom innych ludzi (rodaków), które naruszają podstawowe narodowe reguły postępowania (fundamental national precepts) lub szkodzą długoterminowym interesom narodu/kraju (Schatz, Staub, Lavine, 1999, s. 153; na podobnej zasadzie rozróżnia się patriotyzm demokratyczny i autorytarny, zob. Westheimer, 2007; w polskiej literaturze psychologicznej pojawia się natomiast kategoria patriotyzmu krytycznego, zob. Bilewicz, 2007). Często podkreśla się, że „uosabia on ważne aspekty dobrego obywatelstwa” (Sekerdej, Roccas, 2016), stymulując m.in. zaangażowanie polityczne, poczucie skuteczności (sprawstwa), zainteresowanie polityką i sprawami publicznymi.

Z uwagi na fakt, że przytoczone wyżej ustalenia dotyczące społecznych implikacji patriotyzmu formułowane były głównie w oparciu o dane gromadzone w toku badań empirycznych w społeczeństwie amerykańskim (próby badawcze niejednokrotnie składały się ze studentów) (Schatz, Staub, Lavine, 1999; Richey, 2011), mają one ograniczoną wartość eksplanacyjną dla zrozumienia analogicznych zjawisk w krajach europejskich, w szczególności - postkomunistycznych, gdzie tożsamości narodowe konstruowane są raczej w oparciu o kategorię etosu niż demosu (Tismăneanu, 1998), a dodatkowo wciąż bardzo

\footnotetext{
${ }^{7}$ Staub używa też określenia ,patriotyzm konwencjonalny”.
} 
silne są bariery aktywności obywatelskiej. Źródłem spostrzeżeń, które w pewnym stopniu przeczą pozytywnie zweryfikowanym hipotezom w Stanach Zjednoczonych, mogą być dane z badań nad opinią publiczną w Polsce, które wskazują, że silnym autoidentyfikacjom patriotycznym nie towarzyszy równie silne przekonanie, że patriotyzm może się wyrażać w aktywności społecznej i partycypacji w życiu wspólnoty, a już z pewnością nie znajdują one potwierdzenia w rzeczywistych zachowaniach obywateli. Rezultaty badań autora artykułu nad świadomością społeczną studentów w Polsce świadczą o tym, że patriotyzm kojarzony jest najczęściej z emocjonalnym poziomem więzi, jakie mogą łączyć obywatela z krajem ojczystym czy narodem. W tym sensie utożsamiany jest bardziej z przeżywaniem niż działaniem. Odpowiedzi na pytanie otwarte ${ }^{8}$ można pogrupować w kilka kategorii, opisujących różne wymiary percepcji patriotyzmu (od najczęściej do najrzadziej występujących): 1) miłość do kraju, ojczyzny, przywiązanie; 2) poczucie dumy z bycia Polakiem, szacunek dla symboli narodowych/państwowych; 3) szanowanie historii i kultury (zwyczajów, obyczajów, języka); 4) gotowość do obrony kraju, poświęceń na jego rzecz; 5) zaangażowanie obywatelskie, przestrzeganie prawa. Jeszcze ciekawszych wyników dostarcza raport CBOS z sierpnia 2018 roku. Widoczny jest rozdźwięk pomiędzy deklaracjami na temat zachowań, które potencjalnie stanowią przejawy patriotyzmu, a faktycznymi formami aktywności, które podejmują respondenci. Przykładowo, 85\% pytanych utożsamia patriotyzm z podejmowaniem działań na rzecz społeczności lokalnej, przy czym tylko $13 \%$ przyznaje się, że regularnie podejmuje taką aktywność. Istotnym kontekstem dla właściwego zrozumienia tych danych jest informacja, że $88 \%$ badanych uważa siebie za patriotę (odmiennego zdania jest 8\%). Poniższą tabelę, zawierającą zestawienie odpowiedzi z różnych pytań kwestionariusza, należy interpretować z odpowiednim dystansem. Niezależnie od tego, znajdujące się w niej dane rzucają pewne światło na problem braku spójności opinii obywateli i z pewnością sugerują rewizję poglądów badacza na temat stanu i jakości patriotyzmu Polaków.

Tabela 1

Rozdźwięk pomiędzy deklaracjami a zachowaniami w sferze patriotyzmu (dane w \%)

\begin{tabular}{|c|c|c|c|}
\hline \multicolumn{2}{|l|}{ Deklaracja } & \multicolumn{2}{|l|}{ Rzeczywista aktywność } \\
\hline $\begin{array}{c}\text { Patriotyzmowi nadaje się rozmaite } \\
\text { znaczenia. Czy, Pana(i) zdaniem, } \\
\text { patriotyzm polega na: }\end{array}$ & $\begin{array}{c}\text { Zdecy- } \\
\text { dowanie } \\
\text { tak + Ra- } \\
\text { czej tak }\end{array}$ & Czy i jak często zdarza się Panu(i): & $\begin{array}{c}\text { Bardzo } \\
\text { często } \\
\text { + Dość } \\
\text { często }\end{array}$ \\
\hline $\begin{array}{l}\text { okazywaniu szacunku godtu, fladze } \\
\text { i hymnowi narodowemu }\end{array}$ & 98 & $\begin{array}{l}\text { wywieszać polska flage } w \text { zwiąku } \\
z \quad \text { obchodami świąt } \\
\text { lub przy innych okazjach }\end{array}$ & 44 \\
\hline kibicowaniu polskim sportowcom & 82 & czuć dumę z sukcesów polskich sportowców & 57 \\
\hline znajomości historii swojego kraju & 95 & $\begin{array}{l}\text { czytać, dowiadywać się na temat różnych } \\
\text { wydarzeń z historii Polski }\end{array}$ & 45 \\
\hline $\begin{array}{l}\text { kupowaniu przede wszystkim polskich } \\
\text { produktów }\end{array}$ & 65 & $\begin{array}{l}\text { unikać zakupu produktów, które } \\
\text { nie zostaty wytworzone } w \text { Polsce }\end{array}$ & 21 \\
\hline $\begin{array}{l}\text { podejmowaniu działań na rzecz swojej } \\
\text { społeczności lokalnej, okolicy, w któ- } \\
\text { rej się mieszka }\end{array}$ & 85 & $\begin{array}{l}\text { dobrowolnie i bezpłatnie pracować na rzecz } \\
\text { lokalnej społeczności }\end{array}$ & 13 \\
\hline
\end{tabular}

Źródło: Patriotyzm Polaków, raport CBOS, nr 105/2018.

\footnotetext{
8 „Proszę JEDNYM ZDANIEM opisać, co dla Pana/i oznacza pojęcie PATRIOTYZM”.
} 
Problem, na który zwrócono uwagę być może ma bardziej uniwersalny charakter i dotyczy przede wszystkim młodych ludzi, co podkreślają Joseph Kahne i Ellen Middaugh (2006, s. 603-604). W ich opinii studenci/uczniowie nie doceniają znaczenia i wagi partycypacji i zdarza się, że zarówno „ślepi”, jak i „konstruktywni” patrioci - choć kochają swój kraj - to podobnie nie są zaangażowani ani w sensie politycznym, ani obywatelskim. W związku z tym zamiast mówić o ślepym i konstruktywnym patriotyzmie, powinniśmy raczej rozróżniać jego odmianę pasywną (powiązaną wyłącznie z poznawczo-afektywnymi aspektami przywiązania do kraju) oraz aktywną (polegającą na podejmowaniu konkretnych działań na rzecz grupy, w szczególnych przypadkach nawet poświęcenie życia) (Bar-Tal, 1993, s. 49).

\section{Metodologia badań}

Głównym celem autora niniejszego artykułu jest próba opisania oraz wyjaśnienia, w jakim stopniu (i w jakim zakresie) patriotyzm polskich studentów wpływa na prawdopodobieństwo podejmowania zachowań obywatelskich, prospołecznych i prodemokratycznych? Poszukując odpowiedzi na to pytanie, zostaną zaprezentowane dane uzyskane w ramach projektu badawczego, którego głównym elementem było badanie ankietowe zrealizowane na próbie (losowej wielostopniowej) studentów z 14 największych uniwersytetów w Polsce w okresie między styczniem a majem 2018 roku (N=980). Ważne będzie, aby ustalić - w kontekście zreferowanych wcześniej koncepcji teoretycznych - czy istnieje istotny związek pomiędzy (różnie konceptualizowanym) patriotyzmem studentów a ich aktywnością obywatelską. Pozwoli to z większą precyzją scharakteryzować ich jako pasywnych lub aktywnych patriotów. W toku analizy statystycznej testowana będzie następująca hipoteza badawcza:

H1: Patriotyzm studentów rozumiany jako: a) autoidentyfikacja patriotyczna; b) odczuwanie miłości do ojczyzny; c) poczucie dumy z bycia Polakiem; d) siła identyfikacji z krajem jest pozytywnie skorelowany z poziomem aktywności obywatelskiej.

Rolę zmiennej zależnej w tym przypadku pełni aktywność obywatelska (civic activity), która jest przez autora definiowana dosyć ogólnie jako zaangażowanie w realizację dobra publicznego, które realizuje się zazwyczaj poprzez bezpośrednią współpracę z innymi ludźmi (Zukin i in., 2006, s. 51). Do pomiaru tej zmiennej zastosowano następujące pytanie kwestionariuszowe: „Czy w trakcie OSTATNIEGO ROKU zdarzyło się Panu/ Pani angażować w działania na rzecz społeczności lokalnej (osiedla, miejscowości, parafii, najbliższego sąsiedztwa)?”.

W dalszej części artykułu zostanie wykorzystany konstrukt teoretyczny, który pozwoli opisać poglądy respondentów na skali ślepego/konstruktywnego patriotyzmu oraz dokonać próby zidentyfikowania związków pomiędzy określonym modelem patriotyzmu studentów a ich prospołecznymi i prodemokratycznymi zachowaniami. Wychodząc z założenia, że współczesna demokracja i społeczeństwo obywatelskie potrzebuje konstruktywnych (ale i aktywnych) patriotów, sformułowano kolejne hipotezy:

H2: Konstruktywni częściej niż ślepi patrioci przejmują się tym, czy instytucje demokratyczne dobrze funkcjonuja. 
H3: Konstruktywni częściej niż ślepi patrioci cenia demokrację niż inne formy rzadzenia.

H4: Konstruktywni częściej niż ślepi patrioci angażuja się w aktywność obywatelska, wolontariat $i$ wspieranie akcji charytatywnych.

H5: Konstruktywni patrioci maja większy kapitał społeczny (tj. częściej ufaja innym).

\section{Rezultaty}

Statystyki opisowe dla zmiennych, które zostały użyte w analizie informują, że polscy studenci - przynajmniej na poziomie deklaratywnym - są bardzo patriotyczni. W każdym z czterech wymiarów (opisanych w hipotezie H1) odsetki wskazań na poglądy, wartości czy emocje patriotyczne oscylują wokół 75\%, a w jednym z nich (poczucie dumy) osiągają nawet $83 \%$ (tabela 2 ).

Tabela 2

\section{Cztery wymiary patriotyzmu polskich studentów (dane w \%)}

\begin{tabular}{|c|c|c|}
\hline \multicolumn{3}{|l|}{ WYYMIAR 1: Czy uważa się Pan/i za patriotę/patriotkę? } \\
\hline Zdecydowanie tak & 25,6 & \multirow[t]{2}{*}{75,3} \\
\hline Raczej tak & 49,7 & \\
\hline Raczej nie & 10,2 & \multirow[t]{2}{*}{14,7} \\
\hline Zdecydowanie nie & 4,5 & \\
\hline Trudno powiedzieć & \multicolumn{2}{|c|}{10,0} \\
\hline \multicolumn{3}{|c|}{$\begin{array}{l}\text { WYMIAR 2: Niektórzy staraja się zdefiniować pojęcie patriotyzmu jako „miłość do ojczyzny”. } \\
\text { W jakim stopniu odczuwa Pan/i mitość do Polski? }\end{array}$} \\
\hline Zdecydowanie odczuwam & 29,4 & \multirow[t]{2}{*}{77,8} \\
\hline Raczej odczuwam & 48,4 & \\
\hline Raczej nie odczuwam & 9,5 & \multirow[t]{2}{*}{13,6} \\
\hline Zdecydowanie nie odczuwam & 4,1 & \\
\hline Trudno powiedzieć & \multicolumn{2}{|c|}{8,6} \\
\hline \multicolumn{3}{|l|}{ WYMIAR 3: Czy czuje się Pan/i dumny/a z bycia Polakiem/Polka? } \\
\hline Zdecydowanie tak & 43,2 & \multirow[t]{2}{*}{83,4} \\
\hline Raczej tak & 40,2 & \\
\hline Raczej nie & 5,4 & \multirow[t]{2}{*}{7,4} \\
\hline Zdecydowanie nie & 2,0 & \\
\hline Trudno powiedzieć & \multicolumn{2}{|c|}{9,2} \\
\hline \multicolumn{3}{|c|}{$\begin{array}{l}\text { WYMIAR 4: Jak silny związek czuje Pan/i z wymienionymi grupami czy środowiskami? Odpowiedź: POL- } \\
\text { SKA }\end{array}$} \\
\hline Czuję bardzo silny związek i utożsamiam się z tą grupą & 21,7 & \multirow[t]{2}{*}{73,0} \\
\hline Czuję z tą grupą silny związek & 51,3 & \\
\hline Czuję z tą grupą słaby związek & 20,2 & \multirow[t]{2}{*}{23,7} \\
\hline W ogóle nie czuję związku z tą grupą i zupełnie się z nią nie utożsamiam & 3,5 & \\
\hline Trudno powiedzieć & \multicolumn{2}{|c|}{3,3} \\
\hline
\end{tabular}

Źródło: Opracowanie własne.

Temu wzmożeniu patriotycznych identyfikacji oraz afektywnego przywiązania do własnego kraju nie towarzyszy jednak, widoczna na analogicznym poziomie, gotowość 
do angażowania się w działania na rzecz społeczności lokalnej, choć na tym etapie analizy nie można jeszcze stwierdzić, czy i w jakim stopniu (i zakresie) jest ona determinowana przez odczuwanie i przeżywanie patriotyzmu (tabela 3 ).

Tabela 3

\section{Aktywność obywatelska polskich studentów (dane w \%)}

\begin{tabular}{|c|c||}
\hline \multicolumn{2}{|l||}{$\begin{array}{l}\text { Czy w trakcie OSTATNIEGO ROKU zdarzyło się Panu/Pani angażować w działania na rzecz społeczności } \\
\text { lokalnej (osiedla, miejscowości, parafi, najbliższego sasiedztwa)? }\end{array}$} \\
\hline Tak & 40,9 \\
\hline Nie & 59,1 \\
\hline
\end{tabular}

Źródło: Opracowanie własne.

W celu weryfikacji hipotezy H1 wykorzystano test U Manna-Whitneya, w którym zmienna nominalna (aktywność obywatelska) pełni rolę zmiennej grupującej, a zmienna porządkowa (każdy z czterech wymiarów patriotyzmu a-d) - rolę zmiennej zależnej. Zamiarem takiego działania było sprawdzenie, czy osoby zaangażowane $\mathrm{w}$ pracę na rzecz społeczności lokalnej różniły się od osób, które nie podejmowały aktywności w tym zakresie, pod względem nasilenia cech i właściwości patriotycznych.

Odpowiedzi studentów w każdym wymiarze patriotyzmu mierzone były przy użyciu 5-stopniowej skali. Z uwagi na fakt, że osoby, które udzielały odpowiedzi „Trudno powiedzieć" nie stanowiły więcej niż $10 \%$ próby badawczej, zostały one wyłączone $\mathrm{z}$ analizy. Pozwoliło to uwzględnić w obliczeniach tylko przekonanych do swojej opinii respondentów. Niższe wartości na skali 1-4 każdorazowo oznaczały wyższy poziom patriotyzmu (np. silniejszą identyfikację z własnym krajem). Szczegółowe wyniki zawarto w tabeli 4.

Tabela 4

Wyniki testu U Manna-Whitneya dla zmiennych testowanych w hipotezie H1

Czy w trakcie OSTATNIEGO ROKU zdarzylo się Panu/Pani angażować w dzialania na rzecz spoleczności lokalnej (osiedla, miejscowości, parafii, najbliższego sq̨siedztwa)?

\begin{tabular}{|c|c|c|c|c|c|c|c|}
\hline $\begin{array}{c}\text { Wymiar } \\
\text { patriotyzmu }\end{array}$ & & $\mathbf{N}$ & $\begin{array}{c}\text { Średnia } \\
\text { ranga }\end{array}$ & $\begin{array}{c}\text { Suma } \\
\text { rang }\end{array}$ & $\begin{array}{l}\text { U Manna- } \\
\text { Whitneya }\end{array}$ & $\mathbf{Z}$ & $\mathbf{p}$ \\
\hline \multirow{2}{*}{1} & Tak & 357 & 400,34 & 142921 & \multirow{2}{*}{79018,000} & \multirow{2}{*}{$-2,204$} & \multirow{2}{*}{0,028} \\
\hline & $\mathrm{Nie}$ & 481 & 433,72 & 208620 & & & \\
\hline \multirow{2}{*}{2} & Tak & 359 & 402,97 & 144665,5 & \multirow{2}{*}{80045,500} & \multirow{2}{*}{$-2,642$} & \multirow{2}{*}{0,008} \\
\hline & $\mathrm{Nie}$ & 493 & 443,64 & 218712,5 & & & \\
\hline \multirow{2}{*}{3} & Tak & 352 & 392,28 & 138083 & \multirow{2}{*}{75955,000} & \multirow{2}{*}{$-3,647$} & \multirow{2}{*}{0,000} \\
\hline & $\mathrm{Nie}$ & 497 & 448,17 & 222742 & & & \\
\hline \multirow{2}{*}{4} & Tak & 366 & 423,35 & 154947 & \multirow{2}{*}{87786,000} & \multirow{2}{*}{$-2,703$} & \multirow{2}{*}{0,007} \\
\hline & $\mathrm{Nie}$ & 531 & 466,68 & 247806 & & & \\
\hline
\end{tabular}

Źródło: Opracowanie własne.

Wykonana analiza pozwala wyciągnąć wspólny wniosek dotyczący związków między patriotyzmem a aktywnością obywatelską w każdym z obserwowanych wymiarów 
(tabela 5). Okazuje się, że wszystkie korelacje są istotne statystycznie: w wymiarze 1. na poziomie $\mathrm{p}<0,05$, natomiast $\mathrm{w}$ pozostałych na poziomie $\mathrm{p}<0,001$. Pozwala to pozytywnie zweryfikować hipotezę H1, która mówiła o związku między zmiennymi. Dane szczegółowe nasuwają jednak kilka kolejnych interesujących konkluzji. Średnie rangi dla osób deklarujących zaangażowanie w życie wspólnoty lokalnej są niższe niż dla osób biernych, co sygnalizuje, że cechuje ich wyższy poziom patriotyzmu: silniej identyfikują się jako patrioci, silniej odczuwają miłość do ojczyzny oraz dumę z faktu bycia Polakiem, jak również silniejszy związek z Polską. Pomimo to osoby niepodejmujące żadnej aktywności przeważają zarówno w grupie, która osiąga zarówno niskie, jak i wysokie wartości na skali patriotyzmu w każdym z wymiarów. Cechy opisujące patriotyzm mają znaczenie dla prawdopodobieństwa podejmowania działań na rzecz społeczności lokalnej. Można zauważyć, że patriotyzm osłabia bariery aktywności obywatelskiej, choć nie na tyle, aby można było sformułować wniosek, iż patriotów wyróżnia wysoki poziom aktywizmu. Nie ulega jednak wątpliwości, że patriotyzm stanowi ważny predyktor zaangażowania obywatelskiego.

Tabela 5

Aktywność obywatelska wśród studentów o różnym nasileniu cech patriotycznych (dane w \%)

\begin{tabular}{|c|c|c|c|}
\hline \multicolumn{4}{|c|}{ WYMIAR 1: Autoidentyfikacje } \\
\hline & Słabe $(\mathrm{N}=136)$ & Silne $(N=702)$ & Różnica \\
\hline Aktywni & 33,1 & 44,4 & 11,3 \\
\hline Bierni & 66,9 & 55,6 & $-11,3$ \\
\hline \multicolumn{4}{|c|}{ WYMIAR 2: Miłość do ojczyzny } \\
\hline & Słaba $(N=123)$ & Silna $(N=729)$ & Różnica \\
\hline Aktywni & 35,8 & 43,2 & 7,4 \\
\hline Bierni & 64,2 & 56,8 & $-7,4$ \\
\hline \multicolumn{4}{|c|}{ WYMIAR 3: Poczucie dumy } \\
\hline & Niskie $(\mathrm{N}=69)$ & Wysokie $(\mathrm{N}=780)$ & Różnica \\
\hline Aktywni & 33,3 & 42,2 & 8,9 \\
\hline Bierni & 66,7 & 57,8 & $-8,9$ \\
\hline \multicolumn{4}{|c|}{ WYMIAR 4: Identyfikacja z krajem } \\
\hline & Słaba $(\mathrm{N}=218)$ & Silna $(\mathrm{N}=679)$ & Różnica \\
\hline Aktywni & 34,4 & 42,9 & 8,5 \\
\hline Bierni & 65,6 & 57,1 & $-8,5$ \\
\hline
\end{tabular}

Źródło: Opracowanie własne.

W drugiej kolejności przystąpiono do analizy, mającej na celu weryfikację hipotez H2-H5. W tym przypadku wykorzystano skalę, która pozwoliła na kategoryzację respondentów jako tzw. „ślepych” oraz ,konstruktywnych” patriotów w odniesieniu do koncepcji teoretycznych omawianych wcześniej. Jak już wspomniano, istnieje wiele empirycznych dowodów na to, że konstruktywny patriotyzm (rozumiany jako zespół poglądów) pozytywnie warunkuje m.in. poziom zaangażowania politycznego czy kapitał społeczny jednostek. W literaturze przedmiotu odnaleźć można również argumentacje przeczące tym obserwacjom (Huddy, Khatib, 2007) ${ }^{9}$ oraz - już przytaczany - postulat, aby próbować

${ }^{9} \mathrm{~W}$ pewnych okolicznościach ślepy patriotyzm może również prowadzić do zwiększonej aktywności politycznej (Schatz, Staub, Lavine, 1999, s. 169). 
diagnozować czy typowy dla danej jednostki model patriotyzmu (ślepy/konstruktywny) ma charakter wyłącznie pozanwczo-afektywny czy również behawioralny.

Do mierzenia poglądów na skali ślepego/konstruktywnego patriotyzmu wykorzystano stwierdzenia stosowane w badaniach realizowanych wśród amerykańskich studentów (Schatz, Staub, Lavine, 1999):

1) ludzie, którzy nie odczuwają emocjonalnego związku z Polską powinni zamieszkać gdzieś indziej;

2) polska niemal zawsze postępuje słusznie;

3) popieram swój kraj niezależnie od tego czy ma rację czy nie;

4) uważam, że polityka Polski przeważnie jest moralnie usprawiedliwiona;

5) ludzie nie powinni ciągle próbować zmieniać biegu spraw w Polsce;

6) wielu ludzi na świecie krytykuje Polskę, ale my - jako polscy obywatele - nie powinniśmy tego robić.

Każde z nich było oceniane przez respondentów na 5-stopniowej skali Likerta (Zdecydowanie się zgadzam, Raczej się zgadzam, Ani się zgadzam, ani się nie zgadzam, Raczej się nie zgadzam, Zdecydowanie się nie zgadzam). Dodatkowo, wykorzystano niektóre stwierdzenia ze skali etnocentryzmu, stosowanej w ramach International Social Survey Programme (ISSP), a które - w opinii autora artykułu - dobrze charakteryzują poglądy przypisywane ślepym/konstruktywnym patriotom (m.in. nietolerowanie krytyki, hierarchiczna wizja świata, przekonanie o wyższości własnego kraju):

1) są pewne rzeczy w dzisiejszej Polsce, których wstydzę się jako Polak;

2) świat byłby lepszy, gdyby ludzie z innych krajów byli bardziej podobni do Polaków;

3) ogólnie rzecz biorąc Polska jest lepszym krajem niż większość innych krajów;

4) trzeba popierać swój kraj, nawet jeśli postępuje on niewłaściwie.

Podobnie jak poprzednio, zmienne miały charakter skali porządkowej o wartościach od 1 do 5 . W celu sprawdzenia, czy istniały podstawy do utworzenia jednego zagregowanego wskaźnika patriotyzmu, przeprowadzono analizę składowych głównych (PCA). Na podstawie kryterium osypiska zdecydowano o wyodrębnieniu jednej składowej, która wyjaśniała ogółem $41 \%$ wariancji wyników. Wszystkie zmienne korelowały w silny lub umiarkowany sposób z wyodrębnionym czynnikiem (tabela 6).

Tabela 6

\section{Podsumowanie analizy czynnikowej dla poziomu patriotyzmu ślepego/konstruktywnego}

\begin{tabular}{|l|c|}
\hline \multicolumn{1}{|c|}{ Itemy - treść } & $\begin{array}{c}\text { Składowa } \\
\text { g. } \mathbf{1}\end{array}$ \\
\hline \multicolumn{1}{|c|}{1} & 2 \\
\hline $\begin{array}{l}\text { Ludzie, którzy nie odczuwają emocjonalnego związku z Polską powinni zamieszkać gdzieś } \\
\text { indziej }\end{array}$ & 0,52 \\
\hline Polska niemal zawsze postępuje słusznie & 0,78 \\
\hline Popieram swój kraj niezależnie od tego czy ma rację czy nie & 0,78 \\
\hline Uważam, że polityka Polski przeważnie jest moralnie usprawiedliwiona & 0,72 \\
\hline Ludzie nie powinni ciągle próbować zmieniać biegu spraw w Polsce & 0,47 \\
\hline $\begin{array}{l}\text { Wielu ludzi na świecie krytykuje Polskę, ale my - jako polscy obywatele - nie powinniśmy } \\
\text { tego robić }\end{array}$ & 0,77 \\
\hline Są pewne rzeczy w dzisiejszej Polsce, których wstydzę się jako Polak & 0,49 \\
\hline
\end{tabular}




\begin{tabular}{|l|c|}
\hline \multicolumn{1}{|c|}{1} & 2 \\
\hline Świat byłby lepszy, gdyby ludzie z innych krajów byli bardziej podobni do Polaków & 0,59 \\
\hline Ogólnie rzecz biorąc Polska jest lepszym krajem niż większość innych krajów & 0,63 \\
\hline Trzeba popierać swój kraj, nawet jeśli postępuje on niewłaściwie & 0,57 \\
\hline Wartość własna & 4,13 \\
\hline$[\%]$ wariancji & 41,3 \\
\hline Alfa Cronbacha & 0,83 \\
\hline
\end{tabular}

Źródło: Opracowanie własne.

Utworzony wskaźnik, obliczony poprzez uśrednienie wszystkich itemów, cechował się dopuszczalnymi wynikami z zakresu od 1 do 5, przy czym niższe wartości świadczyły o przewadze patriotyzmu ślepego, a wyższe wartości o przewadze patriotyzmu konstruktywnego. Do analizy rzetelności nowej skali wykorzystano współczynnik Alfa Cronbacha, którego wartość wynosiła 0,83, a zatem można stwierdzić, że zaproponowana skala patriotyzmu ślepego/konstruktywnego cechowała się wysoką zgodnością wewnętrzną. W próbie przeważały osoby cechujące się zespołem poglądów typowych dla patriotyzmu konstruktywnego.

W celu weryfikacji hipotezy H2 przeprowadzono odporną analizę regresji (IRWLS) ${ }^{10}$. W zaproponowanym modelu zmienną objaśnianą był stopień aprobaty stwierdzenia: Jestem bardzo zainteresowany tym, czy nasze demokratyczne instytucje dobrze funkcjonuja mierzony przy pomocy skali pięciostopniowej od 1 (Zdecydowanie się zgadzam) do 5 (Zdecydowanie się nie zgadzam), a predyktorem była skala patriotyzmu. Analiza wykazała, że predyktor był nieistotny statystycznie, a zatem wyniki nie potwierdzają hipotezy (tabela 7). Również wizualizacja wyników przy pomocy wykresów pudełkowych wskazuje, że bez względu na stopień zainteresowania funkcjonowaniem instytucji demokratycznych, poziom patriotyzmu ślepego/konstruktywnego był zbliżony do siebie.

Tabela 7

Parametry modelu regresji odpornej dla zmiennej zależnej: zainteresowanie poprawnym funkcjonowaniem instytucji demokratycznych

\begin{tabular}{|l|c|c|c|c||}
\hline & B & SE & t & p \\
\hline Wyraz wolny & 2,26 & 0,21 & 10,55 & $<0,001$ \\
\hline $\begin{array}{l}\text { Skala patriotyzmu } \\
\text { (ślepy-konstruktywny) }\end{array}$ & 0,05 & 0,06 & 0,82 & 0,412 \\
\hline
\end{tabular}

Źródło: Opracowanie własne.

Respondenci mogli wyrazić swoje poglądy na demokrację, wybierając jedną z czterech opinii ${ }^{11}$ :

a) Demokracja ma zawsze przewage nad wszelkimi innymi formami rząów - zwolennicy;

${ }^{10}$ Pełna nazwa modelu w języku angielskim brzmi: Robust regression based on an M-estimator using iteratively reweighted least squares (IRWLS). ków.

${ }^{11} \mathrm{Z}$ analizy wykluczono odpowiedzi „Trudno powiedzieć”, dlatego próba liczyła 725 przypad- 
b) Niekiedy rzady niedemokratyczne moga być lepsze niż rządy demokratyczne - relatywiści;

c) Dla takich ludzi jak ja nie ma w gruncie rzeczy znaczenia, czy rząd jest demokratyczny czy niedemokratyczny - obojętni;

d) Demokracja jest zła forma rząów - przeciwnicy.

Weryfikację hipotezy H3 zakładającej, że postawa patriotyzmu ślepego/konstruktywnego ma związek ze stosunkiem do demokracji, przeprowadzono przy użyciu porównań zaplanowanych. W tym celu zostały skonstruowane trzy kontrasty ortogonalne. $\mathrm{W}$ pierwszym kontraście porównano grupę zwolenników demokracji ${ }^{12} \mathrm{z}$ grupą relatywistów, obojętnych i przeciwnych w stosunku do tego modelu rządzenia ${ }^{13}$. W drugim kontraście dokonano porównania pomiędzy relatywistami a osobami obojętnymi i przeciwnikami demokracji. Trzeci kontrast obejmował porównanie osób obojętnych i przeciwników demokracji (Tabela 8).

Tabela 8

Poziom patriotyzmu (ślepego/konstruktywnego) w zależności od stosunku do demokracji. Analiza kontrastów ortogonalnych

\begin{tabular}{|l|c|c|c|c|c|c|c|c||}
\hline & \multicolumn{3}{|c|}{ Grupa I } & \multicolumn{3}{c|}{ Grupa II } & \multirow{2}{*}{ t(1) } & \multirow{2}{*}{ p } \\
\cline { 2 - 9 } & $\mathbf{n}$ & $\mathbf{M}$ & SD & n & M & SD & & 0,034 \\
\hline Kontrast 1 & 405 & 3,67 & 0,72 & 320 & 3,57 & 0,73 & 2,13 & 0,269 \\
\hline Kontrast 2 & 258 & 3,59 & 0,69 & 62 & 3,47 & 0,86 & 1,11 & 0,269 \\
\hline Kontrast 3 & 29 & 3,70 & 0,64 & 33 & 3,26 & 0,97 & 2,37 & 0,018 \\
\hline
\end{tabular}

Źródło: Opracowanie własne.

Analiza wykazała, że pierwszy kontrast (najbardziej interesujący z punktu widzenia hipotezy) był istotny statystycznie. Ponieważ średnia wartość na skali patriotyzmu ślepego/konstruktywnego była wyższa w grupie I należy stwierdzić, że zwolennicy demokracji cechowali się większym nasileniem patriotyzmu konstruktywnego, niż osoby mające inny stosunek do tego modelu rządzenia. Różnica ta jest jednak niewielka, co świadczy o słabej sile predyktora.

Drugi kontrast był nieistotny statystycznie, co oznacza, że osoby sceptycznie nastawione do rządów demokratycznych, nie różniły się pod względem patriotyzmu od osób neutralnych i przeciwników demokracji. Wartość trzeciego kontrastu był istotna statystycznie. $Z$ uwagi na to, że w grupie I średnia na skali patriotyzmu była wyższa, niż w grupie II należy wnioskować, że osoby cechujące się postawą neutralną jednocześnie cechowały się silniejszym patriotyzmem konstruktywnym niż przeciwnicy demokracji.

Weryfikację hipotezy H4 zakładającej, że wyższemu nasileniu patriotyzmu konstruktywnego odpowiada silniejsza skłonność do angażowania się w aktywność obywatelską, wolontariat $\mathrm{i}$ wspieranie akcji charytatywnych przeprowadzono w oparciu o model analizy regresji logistycznej z jednym predyktorem (skalą patriotyzmu). Ocenę istotności statystycznej parametrów wszystkich modeli przedstawia tabela 9.

${ }^{12}$ Osoby, które wskazywały odpowiedź: „Demokracja ma zawsze przewagę nad wszelkimi innymi formami rządów".

13 Osoby, które udzielały odpowiedzi innej niż „Demokracja ma zawsze przewagę nad wszelkimi innymi formami rządów". 
Parametry modeli regresji logistycznej z jednym predyktorem (skalą patriotyzmu)

\begin{tabular}{|l|c|c|c|c|c|}
\hline \multicolumn{1}{|c|}{ Predyktor } & B & SE & t & p & OR \\
\hline \multicolumn{7}{|c|}{ Zmienna objaśnia: zaangażowanie w dzialania na rzecz spoleczności lokalne } \\
\hline Wyraz wolny & 0,49 & 0,08 & 5,79 & $<0,001$ & 1,63 \\
\hline Skala patriotyzmu & $-0,02$ & 0,02 & $-1,06$ & 0,290 & 0,98 \\
\hline \multicolumn{7}{|c|}{ Zmienna objaśnia: praca jako wolontariusz } \\
\hline Wyraz wolny & 0,11 & 0,08 & 1,37 & 0,171 & 1,12 \\
\hline Skala patriotyzmu & 0,07 & 0,02 & 3,09 & 0,002 & 1,07 \\
\hline \multicolumn{7}{|l|}{ Zmienna objaśniana: wparcie finansowe akcji charytatywnej } \\
\hline Wyraz wolny & 0,41 & 0,08 & 4,92 & $<0,001$ & 1,51 \\
\hline Skala patriotyzmu & 0,06 & 0,02 & 2,69 & 0,007 & 1,06 \\
\hline \hline
\end{tabular}

Źródło: Opracowanie własne.

Skala patriotyzmu okazała się istotnym i pozytywnym predyktorem w przypadku przewidywania pracy jako wolontariusz i zaangażowania we wsparcie finansowe akcji charytatywnej. Oznacza to, że wyższym wynikom na skali patriotyzmu (większemu nasileniu patriotyzmu konstruktywnego) odpowiadało wyższe prawdopodobieństwo pracy jako wolontariusz i większe prawdopodobieństwo wsparcia finansowego akcji charytatywnej. Do dokładniejszej interpretacji wyników można wykorzystać jednostkowy iloraz szans (OR), który w modelu wolontariatu wynosi 1,07, co oznacza, iż wyższy wynik na skali patriotyzmu o jedną jednostkę był związany ze wzrostem szansy pracy jako wolontariusz o $7 \%$. W przypadku modelu dla zaangażowania $\mathrm{w}$ działanie na rzecz społeczności lokalnych, skala patriotyzmu okazała się predyktorem nieistotnym statystycznie.

W celu weryfikacji hipotezy H5 przeprowadzono odporną analizę regresji(IRWLS). W utworzonym modelu zmienną objaśnianą był stopień zgody ze stwierdzeniem: $C z y$, ogólnie rzecz biorac, ma Pan/i zaufanie do ludzi/nieznajomych, z którymi styka się Pan/i w różnych sytuacjach?, który mierzony był przy pomocy skali 5-stopniowej od 1 (Zdecydowanie tak) do 5 (Zdecydowanie nie), natomiast predyktorem była skala patriotyzmu ślepego/konstruktywnego. Analiza wykazała, że nie był on istotny statystycznie (tabela 10), a zatem nie można potwierdzić hipotezy. Dodatkowo, wizualizacja wyników przy pomocy wykresów pudełkowych wskazuje, że poziom patriotyzmu ślepego/krytycznego był zbliżony bez względu na stopień zaufania do ludzi nieznajomych.

Parametry modelu regresji odpornej dla zmiennej zależnej: zaufanie do ludzi nieznajomych

\begin{tabular}{||l|c|c|c|c|}
\hline & B & SE & t & p \\
\hline Wyraz wolny & 3,48 & 0,20 & 17,37 & $<0,001$ \\
\hline $\begin{array}{l}\text { Skala patriotyzmu } \\
\text { (ślepy-konstruktywny) }\end{array}$ & $-0,10$ & 0,05 & $-1,79$ & 0,075 \\
\hline
\end{tabular}

Źródło: Opracowanie własne. 


\section{Dyskusja i podsumowanie}

Jeśli przyjąć założenie, że życie społeczne organizują wzajemnie stymulujące się fale przeciwnie zorientowanych tendencji, stanowiących skutek sumy ludzkich działań (globalizacja $v s$. lokalizacja, współpraca i integracja $v s$. izolacjonizm i separatyzm itd.), to warto stawiać sobie pytania dotyczące tego, czy i w jakim zakresie można instytucjonalnie bronić się przed przypływem destrukcyjnych i dysfunkcjonalnych postaw, a sprzyjać rozprzestrzenianiu się tych prospołecznych, jak: tolerancja, porozumienie, autoekspresja, współpraca, poczucie skuteczności, zaufanie, umiejętność dochodzenia do kompromisu czy wyrażania własnych opinii (Quintelier, 2008). W niniejszym artykule poszukiwano odpowiedzi na pytanie o to, czy kategoria patriotyzmu może być swoistym „transmiterem” takich postaw.

Wykonane analizy statystyczne prowadzą do generalnej konkluzji, że patriotyzm (niezależnie od tego, jak konceptualizowany) stanowi względnie słaby, choć istotny, predyktor postaw obywatelskich (zarówno w warstwie poznawczej, jak i behawioralnej). W żadnym $\mathrm{z}$ analizowanych przypadków nie okazał się on na tyle silną determinantą aktywności (działań na rzecz społeczności lokalnej), abyśmy mogli stwierdzić, że wśród osób cechujących się wysokim stopniem patriotyzmu przeważają zarazem aktywni i zaangażowani obywatele. Niemniej, widoczny jest wyraźny przyrost respondentów zaangażowanych $\mathrm{w}$ grupie o silniej odczuwanym, przeżywanym i deklarowanym patriotyzmie: średnio o 9\% w każdym z 4 obserwowanych wymiarów. Uzyskane wyniki w części potwierdzają trendy zauważone $\mathrm{w}$ analogicznych badaniach nad młodzieżą studencką w Stanach Zjednoczonych, jednakże w polskim kontekście może istnieć problem z ich precyzyjną interpretacją. Trudno bowiem ocenić, w jaki sposób ujawnione zjawisko opisuje określony etap w dynamicznym procesie zmiany społecznej. Czy, będąc społeczeństwem silnie przywiązanym do idei patriotyzmu i łatwo deklarującym identyfikację z symboliką i wartościami narodowymi, stajemy się zarazem społeczeństwem bardziej obywatelskim? Czy mamy do czynienia z przeobrażeniami świadomości społecznej w zakresie implikacji dla otoczenia, jakie niesie (powinien nieść) za sobą patriotyzm? Z przytoczonych danych wynika, że zaangażowanie obywatelskie rzadziej niż symboliczne formy ekspresji utożsamiane są z patriotyzmem przez młodych Polaków. Wydaje się więc, że - jeśli chcielibyśmy uczynić z patriotyzmu silniejszy bodziec stymulujący postawy prospołeczne - należy próbować nadać mu bardziej utylitarny wymiar. Jest to z pewnością wyzwanie dla wielu instytucji demokratycznych - szkoły, uniwersytetu, mediów, partii politycznych czy organizacji pozarządowych - o czym wspomniano we wstępie do tego artykułu (zob. Nussbaum, 2012). Ustalono także, że podział respondentów wedle kryterium ślepego/konstruktywnego patriotyzmu (rozumianego tutaj raczej jako zespół określonych poglądów) ma raczej słabą moc wyjaśniającą poziom aktywności obywatelskiej, ale również poglądy na demokrację czy zaufanie jako ważny filar kapitału społecznego. Być może jest to wskaźnik słabości edukacji obywatelskiej w Polsce, w której zbyt mało miejsca poświęca się kształtowaniu w młodym człowieku poczucia wartości uczestnictwa $\mathrm{w}$ życiu wspólnoty, po drugie zaś - poczucia sprawstwa (Guzik, Marzęcki, Stach, 2015, s. 19). Uzyskane wyniki potwierdzają, że kategoria patriotyzmu posiada taki ,proobywatelski” potencjał i racjonalne jej komunikowanie może wpłynąć w przyszłości na jakość polskiej demokracji i kondycję społeczeństwa 
obywatelskiego. Ta uwaga wydaje się o tyle istotna, że choć konstruktywni patrioci nie są znacząco bardziej aktywni niż ślepi patrioci, to - o czym świadczą wyniki analizy - odpowiedzi respondentów na skali etnocentryzmu były silnie skorelowane $(\mathrm{r}=0,64)$ z odpowiedziami wskazującymi na ślepy patriotyzm (w przeciwieństwie do patriotyzmu konstruktywnego, $r=-0,04)$. Stąd wniosek, że nie wystarczy bezrefleksyjnie uznawać samego faktu zaangażowania $\mathrm{w}$ działalność organizacji dobrowolnych za pozytywne zjawisko. Ważne jest to, jakiego rodzaju to jest działalność, jakie skutki społeczne rodzi: w jakim stopniu przyczynia się do pełniejszego respektowania zasad demokracji, praworządności, utrwalania demokratycznej kultury politycznej czy kapitału społecznego.

\section{Bibliografia}

Abbott Ph. (2007), The Many Faces of Patriotism, Rowman \& Littlefield, Lanham.

Adorno T. W., Frenkel-Brunswik E., Levinson D. J., Sanford R. N. (1950), The Authoritarian Personality, Harper, New York.

Ariely G. (2018), Evaluations of Patriotism across Countries, Groups, and Policy Domains, „Journal of Ethnic and Migration Studies", vol. 44, nr 3, s. 462-481.

Bar-Tal D. (1993), Patriotism as Fundamental Beliefs of Group Members, „Politics and the Individual”, vol. 3, nr 2, s. 45-62.

Bauman Z. (1997), Glokalizacja, czyli komu globalizacja, a komu lokalizacja, „Studia Socjologiczne”, nr 3, s. 53-69.

Bilewicz M. (2007), Być gorszym. O konsekwencjach zagrożenia tożsamości, w: W poszukiwaniu tożsamości. Humanistyczne rozważania interdyscyplinarne, red. H. Mamzer, Wydawnictwo Naukowe UAM, Poznań.

Blader S. L., Tyler T. R. (2009), Testing and Extending the Group Engagement Model: Linkages between Social Identity, Procedural Justice, Economic Outcomes, and Extrarole Behavior, „Journal of Applied Psychology", nr 94, s. 445-464.

Blank T., Schmidt P. (2003), National identity in a united Germany: Nationalism or patriotism? An empirical test with representative data, „Political Psychology”, nr 24, s. 289-312.

Brzozowska M. (2014), Kłopotliwa miłość: patriotyzm w polskich dyskursach publicystycznych, Wydawnictwo UMCS, Lublin.

Cialdini R. B., Goldstein N. J. (2004), Social Influence: Compliance and Conformity, „Annual Review of Psychology", nr 55, s. 591-621.

Cole J., Durham D. (red.) (2007), Generations and Globalization: Youth, Age, and Family in the New World Economy, Indiana University Press, Bloomington.

Conover P. J., Feldman S. (1987), Memo to NES Board of Overseers Regarding 'Measuring Patriotism and Nationalism', Interuniversity Consortium for Political and Social Research, Ann Arbor.

de Figueiredo R. J. P., Elkins Z. (2003), Are patriots bigots? An inquiry into the vices of in-group pride, „American Journal of Political Science”, vol. 47, nr 1, s. 171-188.

Druckman D. (1994), Nationalism, Patriotism, and Group Loyalty: A Social Psychological Perspective, „Mershon International Studies Review”, vol. 38, nr 1, s. 43-68.

Federico C. M., Golec A., Dial J. L. (2005), The Relationship between the Need for Closure and Support for Military Action against Iraq: Moderating Effects of National Attachment, „Personality and Social Psychology Bulletin", vol. 31, nr 5, s. 621-632.

Federowicz M. (2000), Anticipated Institutions: The Power Of Path-Finding Expectations, w: Democratic and Capitalist Transitions in Eastern Europe, red. M. Dobry, Kluwer Academic Publishers, Dordrecht, s. 91-106. 
Finell E., Zogmaister C. (2015), Blind and Constructive Patriotism, National Symbols and Outgroup Attitudes, „Scandinavian Journal of Psychology”, vol. 56, nr 2, s. 189-197.

Gangl K., Torgler B., Kirchler E. (2016), Patriotism's Impact on Cooperation with the State: An Experimental Study on Tax Compliance, „Political Psychology”, vol. 37, nr 6, s. 867-881.

Guzik A., Marzęcki R., Stach Ł. (2015), Pokolenie '89. Aksjologia i aktywność młodych Polaków, Wydawnictwo Naukowe UP w Krakowie, Kraków.

Habermas J., Derrida J. (2003), Europa, jaka śni się filozofom, „Gazeta Wyborcza” z dnia 10.06.2003, pierwotnie opublikowany 31.05.2003 przez europejskie dzienniki: „Frankfurter Allgemeine Zeitung”, „La Repubblica”, „Neue Zuericher Zeitung”, „El Pais”.

Heaven P. C. L., Rajab D., Ray J. J. (1985), Patriotism, Racism, and the Disutility of the Ethnocentrism Concept, „Journal of Social Psychology”, vol. 125, nr 2, s. 181-185.

Huddy L., Khatib N. (2007), American Patriotism, National Identity, „American Journal of Political Science", vol. 51, nr 1, s. 63-77.

Kahne J., Middaugh E. (2006), Is Patriotism Good for Democracy? A Study of High School Seniors' Patriotic Commitments, „Phi Delta Kappan”, vol. 87, nr 8, s. 600-607.

Karasawa M. (2002), Patriotism, Nationalism, and Internationalism among Japanese Citizens: An Etic-Emic Approach, „Political Psychology”, vol. 23, nr 4, s. 645-666.

Kateb G. (2006), Patriotism and Other Mistakes, Yale University Press, New Haven.

Kosterman R., Feshbach S. (1989), Toward a Measure of Patriotic and Nationalistic Attitudes, „Political Psychology", vol. 10, $\mathrm{nr}$ 2, s. 257-274.

Lewicki P. (2004), Co to znaczy być Europejczykiem? Poszukiwanie tożsamości europejskiej wśród studentów Berlina, „Studia Europejskie”, nr 4, s. 9-27.

Marzęcki R. (2015), The 'drifting generation' without a helmsman. Main obstacles in shaping the relations between the political parties and the youth in Poland, „Slovak Journal of Political Sciences", vol. 15, nr 4, s. 319-351.

Marzęcki R. (2017), How to engage ,, democratic natives”? Political sophistication as important determinant of civic activity of young citizens in new democracies (the case of Poland), „Romanian Journal of Political Science", vol. 17, nr 1, s. 135-169.

Marzęcki R., Stach Ł. (2016), Youth of Today and the Democracy of Tomorrow: Polish Students' Attitudes toward Democracy, „Education and Society”, vol. 34, nr 1, s. 39-59.

Mills C. W. (1959), The Sociological Imagination, Oxford University Press, London.

Mouffe Ch. (2015), Agonistyka. Polityczne myślenie o świecie, Wydawnictwo Krytyki Politycznej, Warszawa.

Müller J. W. (2007), Constitutional Patriotism, Princeton University Press, Princeton.

Nathanson S. (1989), In Defense of 'Moderate Patriotism', „Ethics”, nr 99, s. 535-552.

Nathanson S. (2008), Is Cosmopolitan Anti-Patriotism a Virtue?, w: Patriotism. Philosophical and Political Perspectives, red. I. Primoratz, Routledge, London.

Nowak A. (2005), Powrót do Polski. Szkice o patriotyzmie po „końcu historii” 1989-2005, Arcana, Kraków.

Nussbaum M. C. (2002), Patriotism and Cosmopolitanism, w: For Love of Country, red. M. C. Nussbaum, Beacon, Boston, s. 2-17.

Nussbaum M. C. (2012), Teaching Patriotism: Love and Critical Freedom, „University of Chicago Law Review", nr 79, s. 215-251.

Patriotyzm Polaków (2018), raport CBOS, nr 105/2018.

Putnam R. D. (2000), Bowling alone: The collapse and revival of American community, Simon \& Schuster, New York. 
Quintelier E. (2008), Who Is Politically Active: The Athlete, the Scout Member or the Environmental Activist? Young People, Voluntary Engagement and Political Participation, „Acta Sociologica", vol. 51, nr 4, s. 355-370.

Ray J. J., Furnham A. (1984), Authoritarianism, Conservatism, and Racism, „Ethnic and Racial Studies", nr 7, s. 406-412.

Ray J. J., Lovejoy F. H. (1986), The Generality of Racial Prejudice, „Journal of Social Psychology”, vol. 126, nr 4, s. 563-534.

Ray L. (2007), Globalisation and Everyday Life, Routledge, Abingdon.

Richey S. (2011), Civic Engagement and Patriotism, ,Social Science Quarterly”, vol. 92, nr 4, s. 1044-1056.

Rothstein B. (2003), Social Capital, Economic Growth and Quality of Government: The Causal Mechanism, „New Political Economy”, vol. 8, nr 1, s. 49-71.

Schatz R. T., Staub E., Lavine H. (1999), On the Varieties of National Attachment: Blind Versus Constructive Patriotism, „Political Psychology”, vol. 20, nr 1, s. 151-174.

Sekerdej M., Roccas S. (2016), Love versus Loving Criticism: Disentangling Conventional and Constructive Patriotism, „British Journal of Social Psychology”, vol. 55, nr 3, s. 499-521.

Soutphommasane T. (2012), The Virtuous Citizen: Patriotism in a Multicultural Society, Cambridge University Press, Cambridge.

Staub E. (1997), Blind versus Constructive Patriotism: Moving from Embeddedness in the Group to Critical Loyalty and Action, w: Patriotism in the Lives of Individuals and Nations, red. D. BarTal, E. Staub, Nelson-Hall, Chicago, s. 213-228.

Szafraniec K., Domalewski J., Wasielewski K., Szymborski P., Wernerowicz M. (2017), Zmiana warty. Młode pokolenia a transformacje we wschodniej Europie i Azji, Scholar, Warszawa.

Tajfel H. (1974), Social Identity and Intergroup Behaviour, „Social Science Information”, nr 13, s. 65-93.

Tajfel H., Billig M. G., Bundy R. P., Flament C. (1971), Social Categorisation and Intergroup Behaviour, „European Journal of Social Psychology”, nr 1, s. 149-178.

Tajfel H., Turner J. C. (1986), The Social Identity Theory of Intergroup Behavior, w: Psychology of Intergroup Relations, red. S. Worchel, W. G. Austin, Nelson-Hall, Chicago, s. 7-24.

Terry D. J., Hogg M. A., White K. M. (1999), The Theory of Planned Behaviour: Self-identity, Social Identity and Group Norms, „British Journal of Social Psychology”, nr 38, s. 225-244.

Theiss-Morse E. (2009), Who Counts as an America? The Boundaries of National Identity, Cambridge University Press, New York.

Tismăneanu V. (1998), Fantasies of Salvation: Democracy, Nationalism, and Myth in Post-Communist Europe, Princeton University Press, Princeton.

Urry J. (2003), Global Complexity, Polity Press, Cambridge.

Walicki A. (1991), Trzy patriotyzmy. Trzy tradycje polskiego patriotyzmu i ich znaczenie wspótczesne, Res Publica, Warszawa.

Westheimer J. (red.) (2007), Pledging Allegiance: The Politics of Patriotism in American's Schools, Teachers College Press, New York.

Whiteley P. F. (1999), The Origins of Social Capital, w: Social Capital and European Democracy, red. W. van Deth, M. Maraffi, K. Newton, P. F. Whiteley, Routledge, London.

Wolak J., Dawkins R. (2017), The Roots of Patriotism Across Political Contexts, „Political Psychology", vol. 38, nr 3, s. 391-408.

Zielonka J. (2018), Kontrrewolucja. Liberalna Europa w odwrocie, PWN, Warszawa.

Zukin C., Keeter S., Andolina M., Jenkins K., Delli Carpini M. X. (2006), A New Engagement? Political Participation, Civic Life, and the Changing American Citizen, Oxford University Press, New York. 


\section{A Citizen Patriot? Patriotism as a determinant of civic activity of young Poles}

\section{Summary}

The article is a proposal to look at the category of patriotism as a factor that can play an important role in a process of building a civil society in a post-communist state. The main objective is to describe and explain how strong (and to what extent) the patriotism of Polish students affects the likelihood of undertaking civic, pro-social and pro-democracy behaviors. In search of an answer to this question, the author verified a number of hypotheses assuming a relationship between patriotism (understood in various ways) and behaviors or views that are functional from the point of view of the quality of democracy. The analysis was based on data from a nationwide survey conducted among students from 14 universities in Poland in the period between January and May $2018(\mathrm{~N}=980)$. The results of the statistical analysis lead to the general conclusion that patriotism is a relatively weak but important predictor of civic attitudes.

Key words: patriotism, constructive patriotism, blind patriotism, civic activity, civic society, youth 